ARTICLE

https://doi.org/10.1038/s41467-019-09662-4

\title{
Taming the stability of Pd active phases through a compartmentalizing strategy toward nanostructured catalyst supports
}

Xinwei Yang ${ }^{1}$, Qing $\mathrm{Li}^{1}$, Erjun $\mathrm{Lu}^{2}$, Zhiqiang Wang ${ }^{1}$, Xueqing Gong ${ }^{1}$, Zhiyang Yu ${ }^{2}$, Yun Guo ${ }^{1}$ Li Wang ${ }^{1}$, Yanglong Guo1, Wangcheng Zhan', Jinshui Zhang² \& Sheng Dai (i) ${ }^{3,4}$

The design and synthesis of robust sintering-resistant nanocatalysts for high-temperature oxidation reactions is ubiquitous in many industrial catalytic processes and still a big challenge in implementing nanostructured metal catalyst systems. Herein, we demonstrate a strategy for designing robust nanocatalysts through a sintering-resistant support via compartmentalization. Ultrafine palladium active phases can be highly dispersed and thermally stabilized by nanosheet-assembled $\gamma-\mathrm{Al}_{2} \mathrm{O}_{3}\left(\mathrm{NA}-\mathrm{Al}_{2} \mathrm{O}_{3}\right)$ architectures. The $\mathrm{NA}-\mathrm{Al}_{2} \mathrm{O}_{3}$ architectures with unique flowerlike morphologies not only efficiently suppress the lamellar aggregation and irreversible phase transformation of $\gamma-\mathrm{Al}_{2} \mathrm{O}_{3}$ nanosheets at elevated temperatures to avoid the sintering and encapsulation of metal phases, but also exhibit significant structural advantages for heterogeneous reactions, such as fast mass transport and easy access to active sites. This is a facile stabilization strategy that can be further extended to improve the thermal stability of other $\mathrm{Al}_{2} \mathrm{O}_{3}$-supported nanocatalysts for industrial catalytic applications, in particular for those involving high-temperature reactions.

\footnotetext{
${ }^{1}$ Key Laboratory for Advanced Materials and Research Institute of Industrial Catalysis, School of Chemistry and Molecular Engineering, East China University of Science and Technology, 130 Meilong Road, 200237 Shanghai, China. ${ }^{2}$ State Key Laboratory of Photocatalysis on Energy and Environment College of Chemistry, Fuzhou University, 350116 Fuzhou, China. ${ }^{3}$ Chemical Sciences Division Oak Ridge National Laboratory, University of Tennessee, Knoxville, TN 37996, USA. ${ }^{4}$ Department of Chemistry, University of Tennessee, Knoxville, TN 37996, USA. Correspondence and requests for materials should be addressed to W.Z. (email: zhanwc@ecust.edu.cn) or to J.Z. (email: jinshui.zhang@fzu.edu.cn) or to S.D. (email: dais@ornl.gov)
} 
T he development of thermally robust supported metal nanocatalysts that can undergo high-temperature oxidative or reductive processes is of great interest for industrial catalytic reactions, such as catalytic combustion of hydrocarbons at elevated temperatures and water-gas shift reactions under high temperatures and pressures ${ }^{1-12}$. However, owing to their low Tammann temperatures and high surface energies, catalytically active metal nanoparticles are thermodynamically unstable and tend to sinter or coalescence into larger particles during reactions, especially at high reaction temperatures ${ }^{13-16}$. In addition, phase transformations or the structural collapse of supports at elevated temperatures may exacerbate the sintering or encapsulation of metal nanoparticles ${ }^{17-19}$. Unfortunately, both such thermal behaviours will result in fast deactivation of the catalysts and thus hamper their practical applications in industry. To obtain a sintering-resistant supported nanocatalyst, it is essential to address these issues by employing a suitable host support that can strengthens the metal-support interaction to stabilize metal nanoparticles and provides good mechanical stability to maintain the structural integrity at elevated temperatures ${ }^{20-30}$.

Gamma phase alumina $\left(\gamma-\mathrm{Al}_{2} \mathrm{O}_{3}\right)$ is one of the most popular industrial catalysts and catalyst supports because of its compact crystal structure, excellent mechanical strength, high thermal stability, and robust chemical inertness ${ }^{31-33}$. Recently, it has been proved by high-resolution ${ }^{27} \mathrm{Al}$ nuclear magnetic resonance $\left({ }^{27} \mathrm{Al}\right.$ NMR) that the coordinatively unsaturated pentacoordinate $\mathrm{Al}^{3+}$ $\left(\mathrm{Al}^{3+}{ }_{\text {penta }}\right)$ centers present in $\gamma-\mathrm{Al}_{2} \mathrm{O}_{3}$ can act as binding sites for anchoring metals ${ }^{34}$. This finding is important in which it provides a facile approach to preparing thermally robust supported metal nanocatalysts ${ }^{35,36}$. To better utilize these $\mathrm{Al}^{3+}{ }_{\text {penta }}$ centers to stabilize metals, two-dimensional (2D) $\gamma-\mathrm{Al}_{2} \mathrm{O}_{3}$ nanosheets with open surface structures were synthesized ${ }^{37-39}$. However, because of their huge surface energies, these free-standing $\gamma-\mathrm{Al}_{2} \mathrm{O}_{3}$ nanosheets $\left(\mathrm{N}-\mathrm{Al}_{2} \mathrm{O}_{3}\right)$ tended to stack or agglomerate as bulk ones at elevated temperatures, or even under reaction ${ }^{40}$. This behavior not only induced the loss of the unique structural benefits of nanosheets for heterogeneous catalysis but also, more seriously, resulted in the sintering and/or encapsulation of metal nanoparticles, which rapidly deactivated the catalysts (Fig. 1). Therefore, finding a way to prevent the lamellar aggregation of nanosheets to preserve their unique electronic and structural advantages for stabilizing metals is of significant importance for the fabrication of thermally stable $\gamma-\mathrm{Al}_{2} \mathrm{O}_{3}$ nanosheet-supported catalysts.
The hierarchical assembly of 2D nanosheets into threedimensional (3D) configurations can efficiently overcome the huge surface energies to prevent lamellar stacking, which is clearly demonstrated by the development of 3D graphene, flowerlike $\mathrm{TiO}_{2}$ flakes and nanospherical carbon nitride nanosheet frameworks, and other structures ${ }^{41-48}$. Inspired by this kind of structural arrangement, $\gamma-\mathrm{Al}_{2} \mathrm{O}_{3}$ nanosheets dominated by (110) facets are cross-linked as a hierarchical architecture with a unique flowerlike morphology (Fig. 1). For nanosheet-assembled $\mathrm{Al}_{2} \mathrm{O}_{3}\left(\mathrm{NA}-\mathrm{Al}_{2} \mathrm{O}_{3}\right.$ ), the interconnected topology of the nanosheets provides enough structural rigidity against the surface energies to perfectly stabilize $\gamma-\mathrm{Al}_{2} \mathrm{O}_{3}$ nanosheets against lamellar aggregation and maintain the (110) facets at elevated temperatures. In addition, the thermally induced irreversible $\gamma$-to- $\alpha$ phase transformation is efficiently inhibited by spatially separating the nanosheets from each other to block the surface-controlled phase reactions (Supplementary Fig. 1). As a result, the NA- $\mathrm{Al}_{2} \mathrm{O}_{3}$ architecture serves as a robust host material with unique structural benefits to support metal nanoparticles, and the resultant nanocatalyst exhibits excellent thermal stability and hierarchical structural benefits for heterogeneous catalysis. For example, the $\mathrm{Al}^{3+}{ }_{\text {penta }}$ centers can serve as anchor sites to immobilize ultrafine metal nanoparticles on nanosheets with a strong metal-support interaction ${ }^{34-36}$. And the robust structural interconnectivities of the 3D architecture afford enough mechanical stability to protect the structural integrity against deformation and phase transformation at elevated temperatures, thus efficiently avoiding the sintering and encapsulation of metal nanoparticles caused by support material deformation ${ }^{49-52}$. Furthermore, the flowerlike morphology, with its multifaceted open surfaces, is favorable for mass transfer and made the active metal phases more easily accessible to the reacting molecules. Experimentally, both characteristics are beneficial for heterogeneous catalysis. Hence, it is significant that the ultrafine metals supported on the NA- $\mathrm{Al}_{2} \mathrm{O}_{3}$ architecture are thermally robust for high-temperature oxidative or reductive reactions.

Herein, NA- $\mathrm{Al}_{2} \mathrm{O}_{3}$ hierarchical architectures are fabricated and employed as the host materials to disperse and stabilize ultrafine palladium $(\mathrm{Pd})$ active phases $\left(\mathrm{Pd} / \mathrm{NA}-\mathrm{Al}_{2} \mathrm{O}_{3}\right)$ for high-temperature oxidative reactions. As a result of its robust thermal stability, $\mathrm{Pd} /$ NA- $\mathrm{Al}_{2} \mathrm{O}_{3}$ exhibits an excellent catalytic performance toward combustion of hydrocarbons (e.g. methane and propane) at elevated temperatures. Furthermore, this facile stabilization strategy can be further extended to improve the thermal stability of other

a

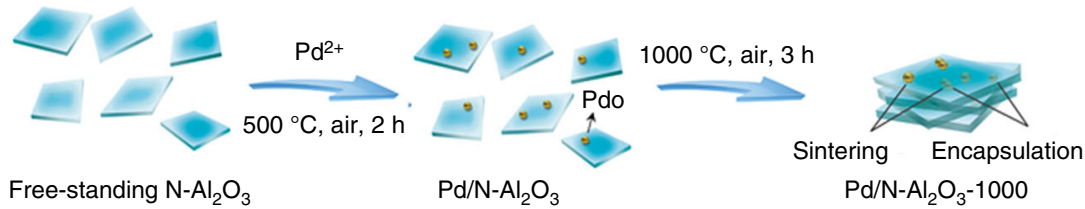

Cross- linked assembly

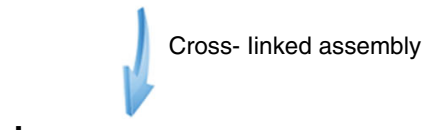

b

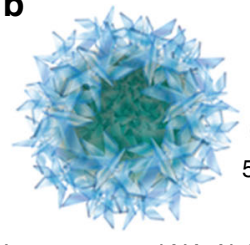

$\mathrm{Pd}^{2+}$

$500^{\circ} \mathrm{C}$, air, $2 \mathrm{~h}$

Interconnected $\mathrm{NA}-\mathrm{Al}_{2} \mathrm{O}_{3}$
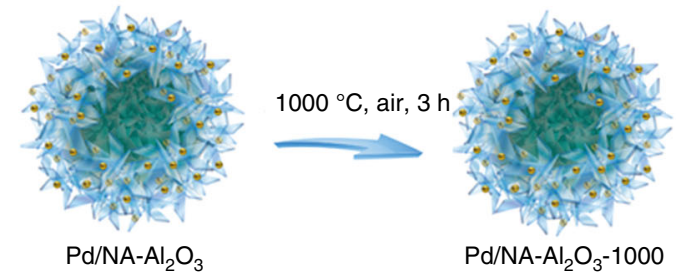

Fig. 1 Illustration of stabilization of $\mathrm{Pd}$ active phases. a Pd active phases stabilized by $\mathrm{N}-\mathrm{Al}_{2} \mathrm{O}_{3}$ in air at $1000^{\circ} \mathrm{C}$. $\mathbf{b}$ Pd active phases stabilized by $\mathrm{NA}-\mathrm{Al} \mathrm{O}_{3}$ in air at $1000^{\circ} \mathrm{C}$ 

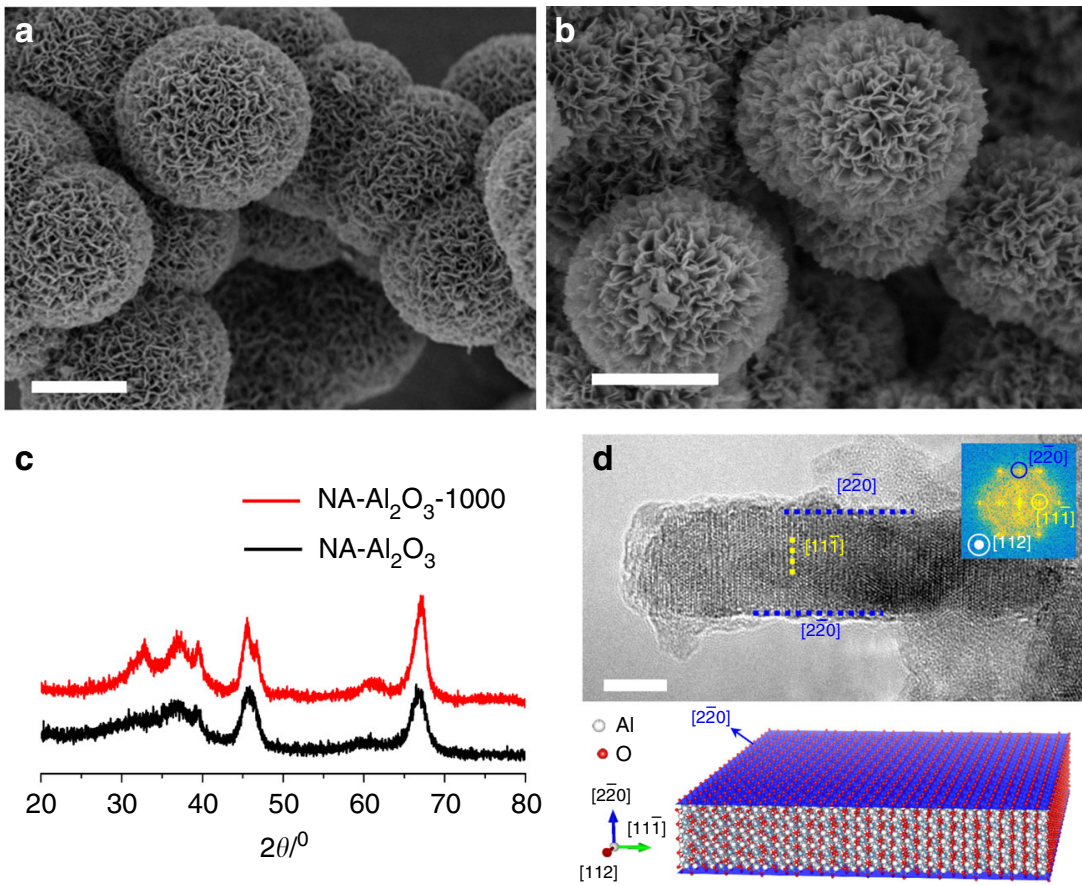

Fig. 2 Thermal characterization of $N A-A_{2} O_{3}$ host materials. a SEM images of $N A-A I_{2} O_{3}$. b SEM images of $N A-A I_{2} O_{3}-1000$. c $X R D$ patterns of $N A-A I_{2} O_{3}$ and $\mathrm{NA}-\mathrm{Al}_{2} \mathrm{O}_{3}-1000$. d HRTEM image of a typical nanosheet of $\mathrm{NA}-\mathrm{Al}_{2} \mathrm{O}_{3}-1000$. Upper panel: It was aligned to an edge-on condition, namely, a condition that the basal surfaces (2亏20) of nanosheets were in parallel with the electron beam. The inset is the FFT pattern recorded from the nanosheet. Lower panel: A schematic diagram showing the geometry of the nanosheets. The two basal planes of the nanosheet are colored blue. The scale bar in (a and b corresponds to $2 \mu \mathrm{m}$, and in $\mathbf{d}$ corresponds to $5 \mathrm{~nm}$

$\mathrm{Al}_{2} \mathrm{O}_{3}$-supported nanocatalysts for industrial catalytic applications, in particular for those involving high-temperature reactions.

\section{Results}

Thermal behavior of $\mathrm{NA}-\mathrm{Al}_{2} \mathrm{O}_{3}$ architectures. Fig. 2 illustrates the thermal stability of $\mathrm{NA}-\mathrm{Al}_{2} \mathrm{O}_{3}$. To evaluate the thermal behavior, the as-prepared $\mathrm{NA}-\mathrm{Al}_{2} \mathrm{O}_{3}$ architectures were subjected to an annealing treatment at $1000{ }^{\circ} \mathrm{C}$ in air for $3 \mathrm{~h}$ (the resultant sample was denoted as $\left.\mathrm{NA}-\mathrm{Al}_{2} \mathrm{O}_{3}-1000\right)$ and then were characterized by means of scanning electron microscopy (SEM), transmission electron microscopy (TEM), atomic force microscope (AFM), $\mathrm{N}_{2}$-sorption analysis, and X-ray diffraction (XRD). In Fig. $2 \mathrm{a}$ and Supplementary Fig. 2, the as-prepared $\mathrm{NA}-\mathrm{Al}_{2} \mathrm{O}_{3}$ architectures were assembled from $\sim 5$-nm-thick flat nanosheets in a highly interconnected fashion to form a hollow spherical morphology; their diameters and shell thicknesses were determined to be $3-6 \mu \mathrm{m}$ and $500-900 \mathrm{~nm}$, respectively. Benefiting from the structural and mechanical advantages of such crosslinked nanosheet networks, which protected against lamellar aggregation, the hierarchical hollow architecture of $\mathrm{NA}-\mathrm{Al}_{2} \mathrm{O}_{3}$ was quite robust and sustained $1000{ }^{\circ} \mathrm{C}$ annealing in air for $3 \mathrm{~h}$ without deformation (Fig. 2b and Supplementary Fig. 3). The specific surface area $\left(\mathrm{S}_{\mathrm{BET}}\right)$ of $\mathrm{NA}-\mathrm{Al}_{2} \mathrm{O}_{3}$ and $\mathrm{NA}-\mathrm{Al}_{2} \mathrm{O}_{3}-1000$ was determined to be 219 and $148 \mathrm{~m}^{2} \mathrm{~g}^{-1}$ (Supplementary Fig. 4), indicating that $\mathrm{NA}-\mathrm{Al}_{2} \mathrm{O}_{3}$ has an excellent thermal stability comparable to commercial La-doped $\gamma-\mathrm{Al}_{2} \mathrm{O}_{3}\left(\mathrm{La}-\mathrm{Al}_{2} \mathrm{O}_{3}, \mathrm{~S}_{\mathrm{BET}}=\right.$ $152 \mathrm{~m}^{2} \mathrm{~g}^{-1}$ for $\mathrm{La}-\mathrm{Al}_{2} \mathrm{O}_{3}, \mathrm{~S}_{\mathrm{BET}}=107 \mathrm{~m}^{2} \mathrm{~g}^{-1}$ for $\mathrm{La}-\mathrm{Al}_{2} \mathrm{O}_{3}-1000$, Supplementary Fig. 5). In addition, the surface structure of the $\mathrm{NA}-\mathrm{Al}_{2} \mathrm{O}_{3}$ also became much more open after the $1000^{\circ} \mathrm{C}$ annealing, which should be kinetically favorable for heterogeneous reactions. On the contrary, obvious structural deformation, particularly layer restacking/agglomeration occurred in the free-standing $\mathrm{N}-\mathrm{Al}_{2} \mathrm{O}_{3}$ (Supplementary Fig. 6). It resulted in the evident decrease of $\mathrm{S}_{\mathrm{BET}}$ from 198 to $78 \mathrm{~m}^{2} \mathrm{~g}^{-1}$, seriously counteracting the structural advantages of the nanosheet morphology for heterogeneous catalysis. The crystallinity of NA$\mathrm{Al}_{2} \mathrm{O}_{3}$ was greatly improved by $1000^{\circ} \mathrm{C}$-annealing treatment, as indicated by the appearance of high-resolution XRD reflections at 32.8 , 37.1, and 39.5, respectively, for (220), (311), and (222) $\gamma$ $\mathrm{Al}_{2} \mathrm{O}_{3}$ (Fig. 2c, JCPDS 10-0425). As a result of the spatial separation of the nanosheets from each other to block the surfacecontrolled phase reactions, the thermally induced phase transformation was well suppressed on the $\mathrm{NA}-\mathrm{Al}_{2} \mathrm{O}_{3}$ architecture; whereas for $\mathrm{N}-\mathrm{Al}_{2} \mathrm{O}_{3}$, an irreversible $\gamma$-to- $\theta$ phase transformation was observed after calcination in air at $1000^{\circ} \mathrm{C}$ for $3 \mathrm{~h}$ (Fig. $2 \mathrm{c}$ vs. Supplementary Fig. 7). To further investigate the thermal stability of $\mathrm{NA}-\mathrm{Al}_{2} \mathrm{O}_{3}$, its hierarchical architectures were deformed by mechanical grinding (denoted as $\mathrm{NA}-\mathrm{Al}_{2} \mathrm{O}_{3}$-deformed) and then subjected to $1000{ }^{\circ} \mathrm{C}$-annealing. Similar to the results obtained from $\mathrm{N}-\mathrm{Al}_{2} \mathrm{O}_{3}-1000$, irreversible $\gamma$-to- $\theta$ phase transformation and significant decrease of $\mathrm{S}_{\mathrm{BET}}$ were observed for $\mathrm{NA}-\mathrm{Al}_{2} \mathrm{O}_{3}$ deformed-1000 $\left(\mathrm{S}_{\mathrm{BET}}=195 \mathrm{~m}^{2} \mathrm{~g}^{-1}\right.$ for $\mathrm{NA}-\mathrm{Al}_{2} \mathrm{O}_{3}$-deformed, $\mathrm{S}_{\mathrm{BET}}=72 \mathrm{~m}^{2} \mathrm{~g}^{-1}$ for $\mathrm{NA}-\mathrm{Al}_{2} \mathrm{O}_{3}$-deformed-1000, Supplementary Fig. 8), further demonstrating the important role of compartmentalization strategy in stabilizing $2 \mathrm{D}$ nanosheets from sintering and collapse. In Fig. 2d, the nanosheet was aligned to edge-on conditions, e.g. [112] zone axis of $\gamma-\mathrm{Al}_{2} \mathrm{O}_{3}$ to study the terminal surfaces of $\mathrm{NA}-\mathrm{Al}_{2} \mathrm{O}_{3}{ }^{53,54}$. As indicated by the clearly resolved lattice fringes of $(2 \overline{2} 0)$ and $(11 \overline{1})$ planes, the preferred surfaces of $\mathrm{NA}-\mathrm{Al}_{2} \mathrm{O}_{3}$ were (110) facets. A schematic diagram was also given to show the geometry of the nanosheet structure. Thus, we conclude that the NA- $\mathrm{Al}_{2} \mathrm{O}_{3}$ architecture with primarily exposed (110) facets is a thermally robust host material and can be used to prepare sintering-resistant supported nanocatalysts.

Thermal behavior of $\mathrm{Pd} / \mathrm{NA}-\mathrm{Al}_{2} \mathrm{O}_{3}$ nanocatalysts. The asprepared $\mathrm{NA}-\mathrm{Al}_{2} \mathrm{O}_{3}$ architectures were directly used to support $\mathrm{Pd}$ active phases through an incipient wet impregnation method 

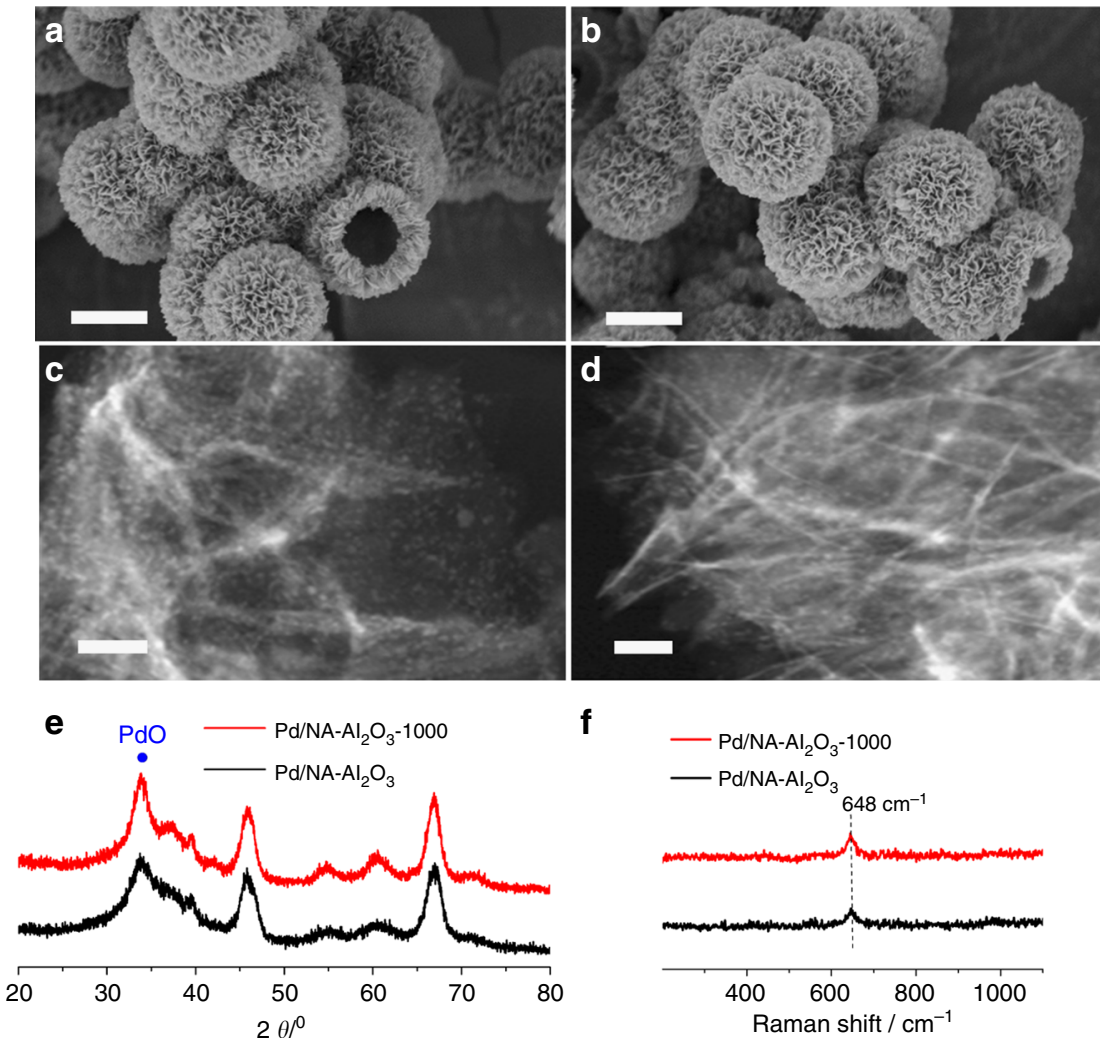

Fig. 3 Thermal characterization of $\mathrm{Pd} / \mathrm{NA}-\mathrm{Al}_{2} \mathrm{O}_{3}$ nanocatalysts. a SEM images of $\mathrm{Pd} / \mathrm{NA}-\mathrm{Al}_{2} \mathrm{O}_{3}$. $\mathbf{b} \mathrm{SEM}$ images of $\mathrm{Pd} / \mathrm{NA}-\mathrm{Al} \mathrm{O}_{2}-1000$. c TEM images of $\mathrm{Pd} / \mathrm{NA}-\mathrm{Al}_{2} \mathrm{O}_{3}$. d TEM images of $\mathrm{Pd} / \mathrm{NA}-\mathrm{Al}_{2} \mathrm{O}_{3}-1000$. e XRD patterns of $\mathrm{Pd} / \mathrm{NA}-\mathrm{Al}_{2} \mathrm{O}_{3}-1000$ and $\mathrm{Pd} / \mathrm{NA}-\mathrm{Al}_{2} \mathrm{O}_{3}$. f Raman spectra of $\mathrm{Pd} / \mathrm{NA}-\mathrm{Al} \mathrm{O}_{3}-1000$ and $\mathrm{Pd} / \mathrm{NA}-\mathrm{Al}_{2} \mathrm{O}_{3}$. The scale bar in $\mathbf{a}$ and $\mathbf{b}$ corresponds to $2 \mu \mathrm{m}$, and in $\mathbf{c}$ and $\mathbf{d}$ corresponds to $50 \mathrm{~nm}$

to load Pd species. To better demonstrate the outstanding ability of $\mathrm{NA}-\mathrm{Al}_{2} \mathrm{O}_{3}$ to stabilize metals, the metal loading was increased to $5 \mathrm{wt} \%$, and the resultant sample was then subjected to annealing at $1000^{\circ} \mathrm{C}$ in air for $3 \mathrm{~h}$ (the samples before and after $1000{ }^{\circ} \mathrm{C}$-annealing are denoted $\mathrm{Pd} / \mathrm{NA}-\mathrm{Al}_{2} \mathrm{O}_{3}$ and $\mathrm{Pd} / \mathrm{NA}-\mathrm{Al}_{2} \mathrm{O}_{3}$ 1000 , respectively). Owing to the excellent stability of the NA$\mathrm{Al}_{2} \mathrm{O}_{3}$ architecture (Fig. 2), $\mathrm{Pd} / \mathrm{NA}-\mathrm{Al}_{2} \mathrm{O}_{3}$ nanocatalysts were sufficiently robust to maintain their structural integrity under $1000{ }^{\circ} \mathrm{C}$-annealing, thus efficiently avoiding the sintering and encapsulation of $\mathrm{Pd}$ nanoparticles caused by nanostructural deformation (Fig. 3a vs. 3b). The $\mathrm{S}_{\mathrm{BET}}$ of $\mathrm{Pd} / \mathrm{NA}-\mathrm{Al}_{2} \mathrm{O}_{3}$ and $\mathrm{Pd} /$ $\mathrm{NA}-\mathrm{Al}_{2} \mathrm{O}_{3}-1000$ was determined to be 152 and $145 \mathrm{~m}^{2} \mathrm{~g}^{-1}$, respectively (Supplementary Fig. 9). Such flowerlike hierarchical structure with well-preserved surface area was beneficial for Pdcatalyzed reactions because it facilitated the transport of reacting molecules to the surface of the catalyst to participate in the reaction 55,56 . The particle sizes of the $\mathrm{Pd}$ active phase were determined to be $2.6 \pm 0.2 \mathrm{~nm}$ and $2.8 \pm 0.2 \mathrm{~nm}$ for $\mathrm{Pd} / \mathrm{NA}-\mathrm{Al}_{2} \mathrm{O}_{3}$ and $\mathrm{Pd} / \mathrm{NA}-\mathrm{Al}_{2} \mathrm{O}_{3}-1000$, respectively (Fig. 3c, d and Supplementary Fig. 9). This result clearly confirms that the $\mathrm{Pd}$ active phase can be well stabilized by $\mathrm{NA}-\mathrm{Al}_{2} \mathrm{O}_{3}$ against sintering at elevated temperatures. In sharp contrast, serious sintering of the Pd active phase with increasing the particle size from $2.5 \pm 0.3 \mathrm{~nm}$ to $75.9 \pm 17.7 \mathrm{~nm}$ and collapse of the $\mathrm{Al}_{2} \mathrm{O}_{3}$ nanosheets with decreasing the $\mathrm{S}_{\mathrm{BET}}$ from 139 to $70 \mathrm{~m}^{2} \mathrm{~g}^{-1}$ occurred in $\mathrm{Pd} /$ $\mathrm{N}-\mathrm{Al}_{2} \mathrm{O}_{3}$, owing to the poor thermal stability of the free-standing nanosheet structure (Supplementary Fig. 10). In addition, NA$\mathrm{Al}_{2} \mathrm{O}_{3}$ with deformed nanostructure (Supplementary Fig. 8) was also used to support Pd species. In Supplementary Fig. 11, evident sintering of $\mathrm{Pd}$ active phases also happened to $\mathrm{Pd} / \mathrm{NA}-\mathrm{Al}_{2} \mathrm{O}_{3}$ deformed-1000, further demonstrating that the compartmentalization of nanosheets plays a critical role in stabilizing Pd active phases. To better study the influence of phase change of alumina on stabilizing $\mathrm{Pd}$ species, $\mathrm{La}-\mathrm{Al}_{2} \mathrm{O}_{3}$ with an excellent thermal stability (Supplementary Fig. 5) was also employed for Pd loading. Similar to the results obtained from $\mathrm{Pd} / \mathrm{N}-\mathrm{Al}_{2} \mathrm{O}_{3}-1000$ and $\mathrm{Pd} / \mathrm{NA}-\mathrm{Al}_{2} \mathrm{O}_{3}$-deformed-1000, an obvious sintering behavior still happened to $\mathrm{Pd} / \mathrm{La}-\mathrm{Al}_{2} \mathrm{O}_{3}-1000$ (Supplementary Fig. 12). These three control experiments underline the structural advantages of nanosheet-assembly hierarchical architectures in stabilizing metals under elevated temperatures. In Supplementary Fig. 13, $\mathrm{Pd} / \mathrm{NA}-\mathrm{Al}_{2} \mathrm{O}_{3}, \mathrm{Pd} / \mathrm{N}-\mathrm{Al}_{2} \mathrm{O}_{3}$, and $\mathrm{Pd} / \mathrm{La}-\mathrm{Al}_{2} \mathrm{O}_{3}$ nanocatalysts were also subjected to an annealing treatment in wet air condition $\left(10 \mathrm{vol} \% \mathrm{H}_{2} \mathrm{O}\right)$ to evaluate their hydrothermal stability for practical catalytic applications. As expected, the ultrafine Pd active phases can be well still stabilized by $\mathrm{NA}-\mathrm{Al}_{2} \mathrm{O}_{3}$ even after calcinated in wet air, whereas significant sintering of $\mathrm{Pd}$ phases occurred to $\mathrm{N}-\mathrm{Al}_{2} \mathrm{O}_{3}$ and $\mathrm{La}-\mathrm{Al}_{2} \mathrm{O}_{3}$ supported samples. This finding demonstrated that $\mathrm{Pd} / \mathrm{NA}-\mathrm{Al}_{2} \mathrm{O}_{3}$ is a promising nanocatalyst that can work under wet air conditions.

Figure $3 \mathrm{e}$ shows the crystal structure of $\mathrm{Pd} / \mathrm{NA}-\mathrm{Al}_{2} \mathrm{O}_{3}$ before and after thermal annealing. Using the unique structural benefits of the hierarchical architecture to suppress the thermally induced phase conversion confirmed that the $\gamma$ phase was the predominant phase for the host $\mathrm{NA}-\mathrm{Al}_{2} \mathrm{O}_{3}$ in both samples. The new diffraction peaks arising at 33.8 and $54.7^{\circ}$ were identified as the characteristic (101) and (112) reflections of palladium oxide (PdO), and no other peak assigned to metallic Pd was observed ${ }^{57,58}$. This finding indicates that the $\mathrm{Pd}$ active phase was stabilized mainly as $\mathrm{PdO}$ nanoparticles on $\mathrm{NA}-\mathrm{Al}_{2} \mathrm{O}_{3}$, even after harsh high-temperature treatment, rather than Pd nanoparticles. It was further confirmed by Raman spectra. In Fig. $3 \mathrm{f}$, the formation of $\mathrm{PdO}$ on $\mathrm{NA}-\mathrm{Al}_{2} \mathrm{O}_{3}$ is clearly identified by the appearance of a characteristic peak assigned to the $\mathrm{B}_{1 \mathrm{~g}}$ mode of $\mathrm{Pd}-\mathrm{O}$ at a Raman shift of $648 \mathrm{~cm}^{-159,60}$. This finding is 

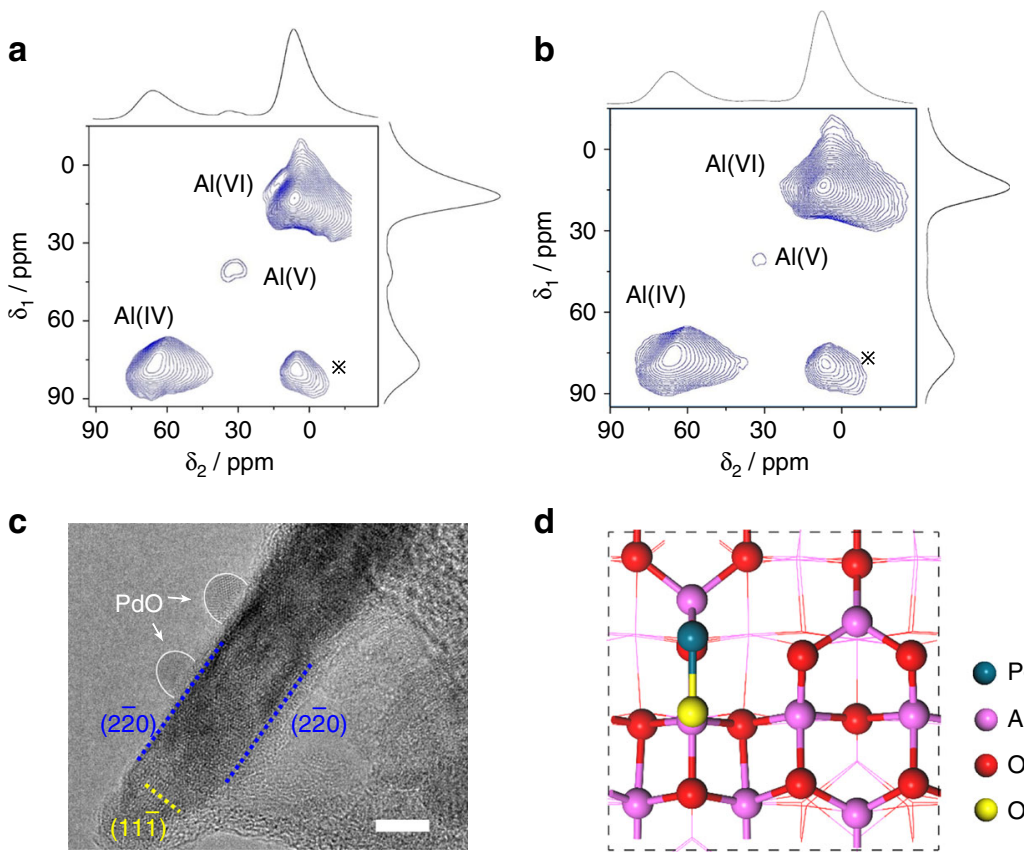

d

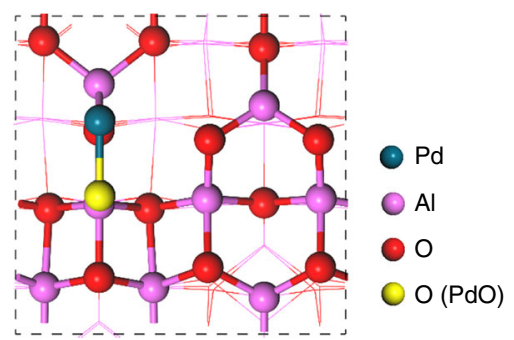

Fig. 4 Structural characterization of $\mathrm{NA}-\mathrm{Al}_{2} \mathrm{O}_{3}$ and $\mathrm{Pd} / \mathrm{NA}-\mathrm{Al}_{2} \mathrm{O}_{3}$. a Two-dimensional ${ }^{27} \mathrm{Al} \mathrm{MQ} \mathrm{MAS} \mathrm{NMR}$ spectra of $\mathrm{NA}-\mathrm{Al} \mathrm{O}_{2}$. b Two-dimensional ${ }^{27} \mathrm{AI}$ MQ MAS NMR spectra of $\mathrm{Pd} / \mathrm{NA}-\mathrm{Al}_{2} \mathrm{O}_{3}$. c TEM image of Pd/NA-AI $\mathrm{O}_{3}-1000$. d Calculated structure of Pd/NA-Al $\mathrm{O}_{3}$. The scale bar in c corresponds to $5 \mathrm{~nm}$

apparently inconsistent with the fact that $\mathrm{PdO}$ will transform into metallic Pd when being subjected to $1000^{\circ} \mathrm{C}$-annealing in air ${ }^{61,62}$. To better solve this issue, a control experiment that cooling down the $\mathrm{Pd} / \mathrm{NA}-\mathrm{Al}_{2} \mathrm{O}_{3}$ nanocatalyst in $\mathrm{N}_{2}$ was carried out after annealing the sample at $1000^{\circ} \mathrm{C}$ in air. As demonstrated in Supplementary Fig. 14, the high-temperature induced decomposition of $\mathrm{PdO}$ indeed happened to $\mathrm{Pd} / \mathrm{NA}-\mathrm{Al}_{2} \mathrm{O}_{3}$ nanocatalyst, and the PdO was partially transformed into metallic $\mathrm{Pd}$ when cooled down in $\mathrm{N}_{2}$. But why is only PdO phase determined in $\mathrm{Pd} / \mathrm{NA}$ $\mathrm{Al}_{2} \mathrm{O}_{3}-1000$ ? The reason should be mainly attributed to that $\mathrm{Pd}$ active phases can be well stabilized in ultrasmall size by $\mathrm{NA}-\mathrm{Al}_{2} \mathrm{O}_{3}$ (Supplementary Fig. 9), which facilitates the completely reoxidization of metallic Pd back to PdO phase by air during the cooling process. This finding was further confirmed by the results obtained from $\mathrm{N}-\mathrm{Al}_{2} \mathrm{O}_{3}, \quad \mathrm{La}-\mathrm{Al}_{2} \mathrm{O}_{3}$, and $\mathrm{NA}-\mathrm{Al}_{2} \mathrm{O}_{3}$-deformed supported samples. In Supplementary Fig. 15, owing to the evident sintering of $\mathrm{Pd}$ active phases, the arising of metallic $\mathrm{Pd}$ reflection at $40.1^{\circ}$ was observed on $\mathrm{Pd} / \mathrm{N}-\mathrm{Al}_{2} \mathrm{O}_{3}-1000, \mathrm{Pd} / \mathrm{La}-\mathrm{Al}_{2} \mathrm{O}_{3}-1000$ and $\mathrm{Pd} / \mathrm{NA}$ $\mathrm{Al}_{2} \mathrm{O}_{3}$-deformed-1000 samples, indicating that $\mathrm{PdO}$ had been partially transformed into metallic $\mathrm{Pd}$, even when they were cooled down in air. The $\mathrm{Pd}$ dispersion of $\mathrm{Pd} / \mathrm{NA}-\mathrm{Al}_{2} \mathrm{O}_{3}, \mathrm{Pd} / \mathrm{N}-\mathrm{Al}_{2} \mathrm{O}_{3}$ and $\mathrm{Pd} / \mathrm{La}-\mathrm{Al}_{2} \mathrm{O}_{3}$ before and after the $1000^{\circ} \mathrm{C}$-annealing treatment was summarized in Supplementary Table 1. Hence, it is clear that the $\mathrm{Pd}$ active phase was highly dispersed and stabilized as ultrasmall $\mathrm{PdO}$ nanoparticles by $\mathrm{NA}-\mathrm{Al}_{2} \mathrm{O}_{3}$ at elevated temperatures in air, so supported $\mathrm{Pd}$ species in the oxidation state were favorable for high-temperature oxidation reactions. It should be noted that if $\mathrm{PdO}$ active phases had been previously reduced by $\mathrm{H}_{2}$, the resultant metallic Pd nanoparticles can be also well stabilized by $\mathrm{NA}-\mathrm{Al}_{2} \mathrm{O}_{3}$ from sintering, even after $1000^{\circ} \mathrm{C}$-annealing in $\mathrm{N}_{2}$ (Supplementary Fig. 16a). In sharp comparison, sintering of metallic $\mathrm{Pd}$ was observed on $\mathrm{N}-\mathrm{Al}_{2} \mathrm{O}_{3}$ and $\mathrm{La}-\mathrm{Al}_{2} \mathrm{O}_{3}$ supported nanocatalysts (Supplementary Fig. 16b, c). Hence, by taking advantage of the unique nanostructure of $\mathrm{NA}-\mathrm{Al}_{2} \mathrm{O}_{3}$, in particular compartmentalized 2D nanosheets with enlarged surface structure, $\mathrm{Pd}$ active species, either in oxidative or metallic phases can be well stabilized by $\mathrm{NA}-\mathrm{Al}_{2} \mathrm{O}_{3}$ at elevated temperatures.
Strong interaction between $\mathbf{P d O}$ and $\mathrm{NA}-\mathrm{Al}_{2} \mathbf{O}_{3}$. In Fig. 4 , the interaction between $\mathrm{PdO}$ and $\mathrm{NA}-\mathrm{Al}_{2} \mathrm{O}_{3}$ is investigated by $2 \mathrm{D}{ }^{27} \mathrm{Al}$ NMR spectra, high-resolution (HR)-TEM imaging, and theoretical calculation. In the NMR spectra, three distinct peaks centered at 7, 32 , and $65 \mathrm{ppm}$ chemical shifts are observed on the as-prepared $\mathrm{NA}-\mathrm{Al}_{2} \mathrm{O}_{3}$ host materials (Fig. 4a), which were assigned to the $\mathrm{Al}^{3+}$ ions in octahedral $\left(\mathrm{Al}^{3+}{ }_{\text {octa }}\right)$, pentahedral $\left(\mathrm{Al}^{3+}{ }_{\text {penta }}\right)$ and tetrahedral $\left(\mathrm{Al}^{3+}{ }_{\text {tetra }}\right)$ coordination, respectively ${ }^{63-65}$. Among them, the $\mathrm{Al}^{3+}{ }_{\text {penta }}$ sites are considered as the primary anchoring sites for active catalytic phases and should play an essential role in the dispersion and stabilization of Pd oxide species ${ }^{34-36}$. Upon loading of the $\mathrm{PdO}$ on $\mathrm{NA}-\mathrm{Al}_{2} \mathrm{O}_{3}$, the intensity of the peak $\mathrm{Al}^{3+}{ }_{\text {penta }}$ decreased significantly, indicating that most of the $\mathrm{Al}^{3+}{ }_{\text {penta }}$ sites had been used to immobilize $\mathrm{Pd}$ oxides on $\mathrm{Al}_{2} \mathrm{O}_{3}$ nanosheets (Fig. 4b) $)^{37}$. In Fig. 4c, the growth of $\mathrm{PdO}$ onto $\mathrm{Al}_{2} \mathrm{O}_{3}$ is confirmed by the HRTEM images, where Pd active phases sitting on the (110) surfaces of $\gamma-\mathrm{Al}_{2} \mathrm{O}_{3}$ nanosheets was clearly resolved. The energetics of the interaction of $\mathrm{PdO}$ with the (110) facets of $\gamma-\mathrm{Al}_{2} \mathrm{O}_{3}$ were studied by theoretical calculations In Fig. $4 \mathrm{~d}$, the sitting of $\mathrm{PdO}$ on (110) facets of $\gamma-\mathrm{Al}_{2} \mathrm{O}_{3}$ is exothermic, and the corresponding adsorption energy is determined to be $3.16 \mathrm{eV}$. This finding suggested that the $\mathrm{Pd}$ active phase supported on the (110) facets of $\gamma-\mathrm{Al}_{2} \mathrm{O}_{3}$ is thermodynamically stable, and large energy would be required for $\mathrm{Pd}-\mathrm{O}$ bond breaking if the $\mathrm{Pd}$ phase started to migrate and sinter. Hence, the (110) facets of $\gamma-\mathrm{Al}_{2} \mathrm{O}_{3}$ thermodynamically facilitated the stabilization of the $\mathrm{Pd}$ active phase against sintering. The preservation of the structural integrity of $\gamma-\mathrm{Al}_{2} \mathrm{O}_{3}$ nanosheets to retain their (110) facets is therefore favorable for the preparation of robust sintering-resistant catalysts.

Catalytic performance in methane combustion. Owing to the unique catalytic ability of $\mathrm{Pd}$ species in oxidation reactions, synthesized $\mathrm{Pd} / \mathrm{Al}_{2} \mathrm{O}_{3}$ catalysts were subjected to methane oxidation at elevated temperatures for the purpose of better evaluating their catalytic performance, particularly thermal stability and catalytic durability. In Fig. 5a, obvious size-dependent 

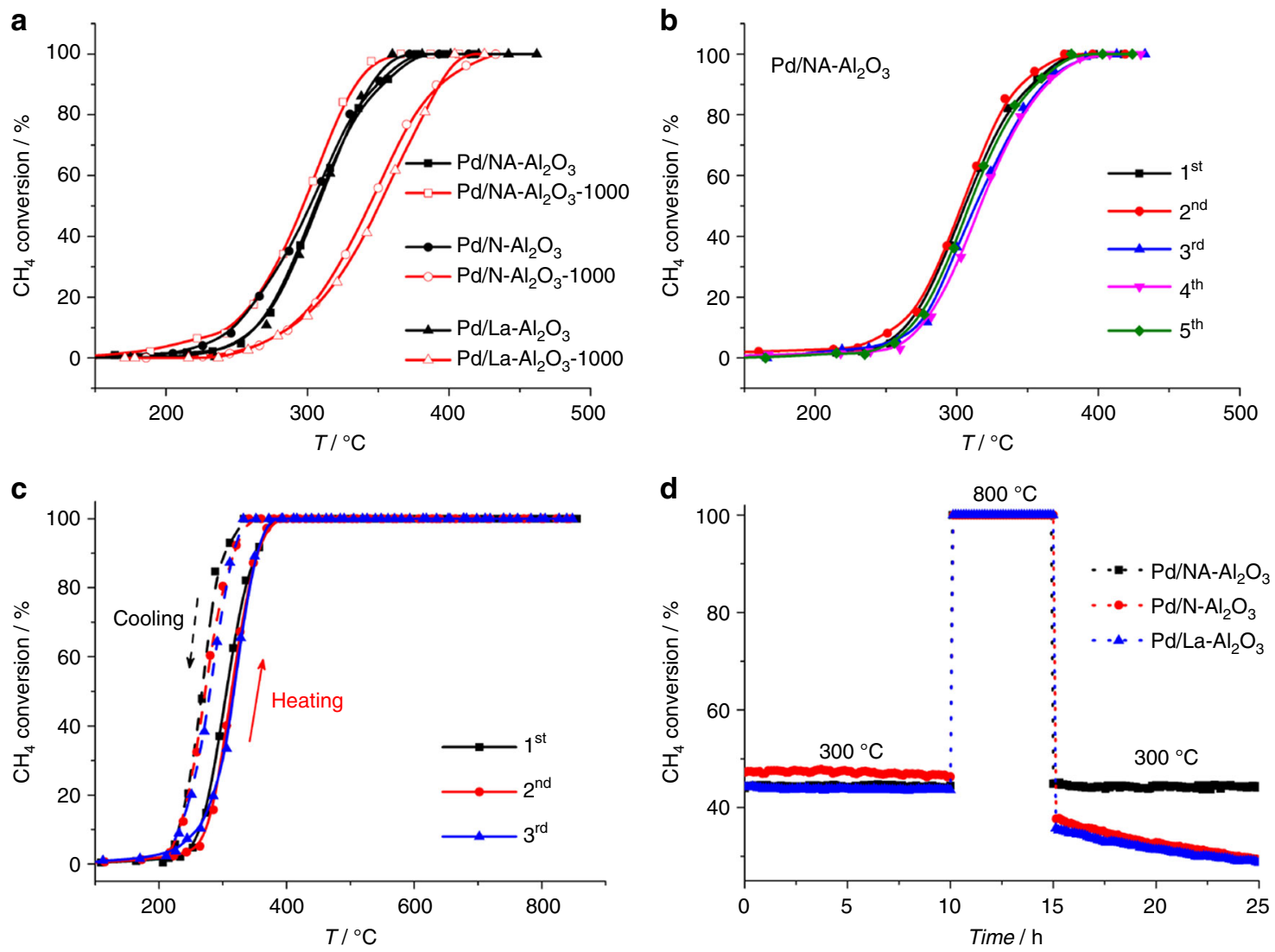

Fig. 5 Catalytic combustion of methane on $\mathrm{Pd} / \mathrm{Al}_{2} \mathrm{O}_{3}$ nanocatalysts. a $\mathrm{CH}_{4}$ conversion vs reactor temperature. $\mathbf{b}$ Repeating ignition-extinction cycles of methane conversion on $\mathrm{Pd} / \mathrm{NA}-\mathrm{Al}_{2} \mathrm{O}_{3}$. $\mathbf{c}$ Light-off curves of methane conversion on $\mathrm{Pd} / \mathrm{NA}-\mathrm{Al}_{2} \mathrm{O}_{3}$ at temperatures between $100-850{ }^{\circ} \mathrm{C}$. $\mathbf{d}$ Long-term combustion of methane at $300-800-300{ }^{\circ} \mathrm{C}$ on $\mathrm{Pd} / \mathrm{NA}-\mathrm{Al}_{2} \mathrm{O}_{3}, \mathrm{Pd} / \mathrm{N}-\mathrm{Al}_{2} \mathrm{O}_{3}$ and $\mathrm{Pd} / \mathrm{La}-\mathrm{Al}_{2} \mathrm{O}_{3}$

catalytic behavior toward methane oxidation was observed on $\mathrm{Pd} / \mathrm{Al}_{2} \mathrm{O}_{3}$ nanocatalysts. For example, a significant loss of activity was determined for $\mathrm{Pd} / \mathrm{N}-\mathrm{Al}_{2} \mathrm{O}_{3}$ and $\mathrm{Pd} / \mathrm{La}-\mathrm{Al}_{2} \mathrm{O}_{3}$ after $1000{ }^{\circ} \mathrm{C}$ annealing, which was due to the evident growth and/or encapsulation of $\mathrm{PdO}$ under high temperatures $\left(\mathrm{Pd} / \mathrm{N}-\mathrm{Al}_{2} \mathrm{O}_{3}\right.$ vs. $\mathrm{Pd} / \mathrm{N}$ $\mathrm{Al}_{2} \mathrm{O}_{3}-1000$, and $\mathrm{Pd} / \mathrm{La}-\mathrm{Al}_{2} \mathrm{O}_{3}$ vs. $\mathrm{Pd} / \mathrm{La}-\mathrm{Al}_{2} \mathrm{O}_{3}-1000$ ). In contrast, the catalytic activity of $\mathrm{Pd} / \mathrm{NA}-\mathrm{Al}_{2} \mathrm{O}_{3}$ was actually slightly better after thermal annealing $\left(\mathrm{Pd} / \mathrm{NA}-\mathrm{Al}_{2} \mathrm{O}_{3}\right.$ vs. $\mathrm{Pd} / \mathrm{NA}-\mathrm{Al}_{2} \mathrm{O}_{3}$ 1000). According to the literature, this improved performance is attributable to the good stabilization of PdO nanoparticles without sintering and the strengthening of the metal-support interaction by high-temperature annealing ${ }^{66-69}$. In Supplementary Fig. 17, a similar size-dependent catalytic behavior toward propane combustion was also observed, further confirming the thermal-induced size evolution of $\mathrm{PdO}$ nanoparticles in these nanocatalysts. To evaluate their catalytic stability, several control experiments were carried out. First are the successive ignitionextinction cycles for methane oxidation. For $\mathrm{Pd} / \mathrm{NA}-\mathrm{Al}_{2} \mathrm{O}_{3}$, the catalytic performance was rather robust without activity loss over five runs (Fig. 5b); whereas for $\mathrm{Pd} / \mathrm{N}-\mathrm{Al}_{2} \mathrm{O}_{3}$ and $\mathrm{Pd} / \mathrm{La}-\mathrm{Al}_{2} \mathrm{O}_{3}$, a significant loss of activity toward to a higher reaction temperature occurred immediately in the second run (Supplementary Fig. 18), due to the sintering of $\mathrm{PdO}$ nanoparticles at the first run. To indicate the stability under hydrothermal condition, water vapor $(\sim 10$ vol\%) was introduced to the reaction system. In Supplementary Fig. 19, $\mathrm{Pd} / \mathrm{NA}-\mathrm{Al}_{2} \mathrm{O}_{3}$ still exhibited a robust catalytic durability over $\mathrm{Pd} / \mathrm{N}-\mathrm{Al}_{2} \mathrm{O}_{3}$ and $\mathrm{Pd} / \mathrm{La}-\mathrm{Al}_{2} \mathrm{O}_{3}$ nanocatalysts for the catalytic combustion of methane in the present of water ( 10 vol\%), because of its sintering-resistant PdO nanoparticles in wet air (Supplementary Fig. 13). To demonstrate that PdO phases are stabilized during methane combustion, the heating/cooling ramps were collected. In Fig. 5c and Supplementary Fig. 20, the typical hysteresis curve caused by $\mathrm{PdO}-\mathrm{Pd}-\mathrm{PdO}$ transformation during cooling process was absent in all $\mathrm{Pd} / \mathrm{Al}_{2} \mathrm{O}_{3}$ nanocatalysts, indicating that $\mathrm{Pd}$ active phases had been well stabilized in oxidative state for methane oxidation ${ }^{70}$. As a result of being heated to a higher temperature ( 850 vs. $450{ }^{\circ} \mathrm{C}$ ) to induce obvious sintering, the activity loss of $\mathrm{Pd} / \mathrm{N}-\mathrm{Al}_{2} \mathrm{O}_{3}$ and $\mathrm{Pd} / \mathrm{La}-\mathrm{Al}_{2} \mathrm{O}_{3}$ became much more evidence in the light-off curves (Fig. 5a vs Supplementary Fig. 20). To better study the influence of reaction temperatures on catalytic activity, long-term operation of methane combustion at alternating reaction temperatures (e.g. 300-800$300{ }^{\circ} \mathrm{C}$ ) was carried out. In Fig. $5 \mathrm{~d}$, each of the three catalysts exhibited a comparable catalytic stability in the first $10 \mathrm{~h}$-run at $300{ }^{\circ} \mathrm{C}$; but after being accelerated aging at $800^{\circ} \mathrm{C}$ for $5 \mathrm{~h}$, a significant loss of activity was observed for $\mathrm{Pd} / \mathrm{N}-\mathrm{Al}_{2} \mathrm{O}_{3}$ and $\mathrm{Pd} / \mathrm{La}-\mathrm{Al}_{2} \mathrm{O}_{3}$ when ramping the reaction temperature back to 300 ${ }^{\circ} \mathrm{C}$. Interesting, $\mathrm{Pd} / \mathrm{NA}-\mathrm{Al}_{2} \mathrm{O}_{3}$ demonstrated a robust catalytic durability during this process. Hence, it can be concluded that the nanosheet-interconnected hierarchical architecture played an essential role in stabilizing $\mathrm{PdO}$ nanoparticles for catalysis, and the resultant $\mathrm{Pd} / \mathrm{NA}-\mathrm{Al}_{2} \mathrm{O}_{3}$ was a robust sintering-resistant catalyst suitable for high-temperature oxidation reactions (Supplementary Fig. 21).

\section{Discussion}

In this study, we demonstrated that ultrafine Pd active phases were well stabilized by an $\mathrm{NA}-\mathrm{Al}_{2} \mathrm{O}_{3}$ architecture as a promising sintering-resistant nanocatalyst for high-temperature oxidation reactions. Such cross-linked $\gamma-\mathrm{Al}_{2} \mathrm{O}_{3}$ nanosheets with flowerlike morphologies provided enough structural rigidity to efficiently suppress lamellar aggregation and the irreversible phase 
transformation of $\gamma-\mathrm{Al}_{2} \mathrm{O}_{3}$ nanosheets at elevated temperatures to avoid the sintering and encapsulation of Pd active phases. In addition, the flowerlike morphologies with multifaceted open surfaces demonstrated significant structural advantages for heterogeneous reactions, such as fast mass transport and easily accessible active sits. As a result, $\mathrm{Pd} / \mathrm{NA}-\mathrm{Al}_{2} \mathrm{O}_{3}$ nanocatalysts exhibited excellent catalytic activity and durability for methane combustion at high temperatures. We hope this facile synthetic strategy can be further extended to improve the thermal stability of other $\mathrm{Al}_{2} \mathrm{O}_{3}$ supported nanocatalysts for industrial catalytic applications, particularly those involving high-temperature reactions.

\section{Methods}

Synthesis of nanosheet-assembled $\mathbf{A l}_{2} \mathbf{O}_{\mathbf{3}}\left(\mathbf{N A}-\mathbf{A l}_{2} \mathbf{O}_{3}\right.$ ). In all, $1.51 \mathrm{~g}$ of Al $\left(\mathrm{NO}_{3}\right)_{3} \cdot 9 \mathrm{H}_{2} \mathrm{O}, 0.70 \mathrm{~g}$ of $\mathrm{K}_{2} \mathrm{SO}_{4}$, and $0.50 \mathrm{~g}$ of $\mathrm{CO}\left(\mathrm{NH}_{2}\right)_{2}$ were dissolved in $80 \mathrm{~mL}$ deionized water. Then the obtained mixture was transferred into a $100 \mathrm{~mL}$ Teflonlined stainless steel autoclave and heated at $180^{\circ} \mathrm{C}$ for $3 \mathrm{~h}$. When cooled to room temperature, the white precipitate was collected by filtration, dried at $80^{\circ} \mathrm{C}$ for $12 \mathrm{~h}$ and finally calcined at $500^{\circ} \mathrm{C}$ for $2 \mathrm{~h}$.

Synthesis of $\mathbf{A l}_{\mathbf{2}} \mathbf{O}_{\mathbf{3}}$ nanosheet $\left(\mathbf{N}-\mathbf{A l}_{\mathbf{2}} \mathbf{O}_{\mathbf{3}}\right)$. The typical procedure to synthesize thin alumina nanosheet was as follows: $0.60 \mathrm{~g}$ of $\mathrm{Al}\left(\mathrm{NO}_{3}\right)_{3} \cdot 9 \mathrm{H}_{2} \mathrm{O}, 0.24 \mathrm{~g}$ of lysine, and $0.77 \mathrm{~g}$ of $\mathrm{CO}\left(\mathrm{NH}_{2}\right)_{2}$ were dissolved in $80 \mathrm{~mL}$ deionized water to form a homogeneous solution under magnetic stirring. Then the solution was transferred into a $100 \mathrm{~mL}$ Teflon-lined stainless autoclave and heated at $100^{\circ} \mathrm{C}$ for $24 \mathrm{~h}$. After cooled to room temperature, the white precipitate was filtered, washed with deionized water and anhydrous alcohol several times, and then dried at $80^{\circ} \mathrm{C}$ for $12 \mathrm{~h}$. The sample was gained after calcination of the powder in air at $500^{\circ} \mathrm{C}$ for $2 \mathrm{~h}$ with a heating rate of $1^{\circ} \mathrm{C} \mathrm{min}^{-1}$

Preparation of Pd/NA-Al $\mathbf{O}_{\mathbf{3}} .5 \mathrm{wt} \%$ Pd active phases were loaded on $\mathrm{NA}-\mathrm{Al}_{2} \mathrm{O}_{3}$ by incipient wet impregnation method and dried at $80^{\circ} \mathrm{C}$ for $12 \mathrm{~h}$. The obtained samples were then calcined at $500{ }^{\circ} \mathrm{C}$ for $2 \mathrm{~h}$. $\mathrm{Pd} / \mathrm{N}-\mathrm{Al}_{2} \mathrm{O}_{3}$ and $\mathrm{Pd} / \mathrm{La}-\mathrm{Al}_{2} \mathrm{O}_{3}$ were prepared with the same method.

Preparation of $\mathbf{P d} / \mathbf{N A}-\mathrm{Al}_{\mathbf{2}} \mathbf{O}_{\mathbf{3}}-\mathbf{- 1 0 0 0}$. The as-prepared $\mathrm{Pd} / \mathrm{NA}-\mathrm{Al}_{2} \mathrm{O}_{3}, \mathrm{Pd} / \mathrm{N}$ $\mathrm{Al}_{2} \mathrm{O}_{3}$, and $\mathrm{Pd} / \mathrm{La}-\mathrm{Al}_{2} \mathrm{O}_{3}$ were calcined at $1000^{\circ} \mathrm{C}$ for $3 \mathrm{~h} . \mathrm{Pd} / \mathrm{N}-\mathrm{Al}_{2} \mathrm{O}_{3}-1000$ and $\mathrm{Pd} / \mathrm{La}-\mathrm{Al}_{2} \mathrm{O}_{3}-1000$ were prepared with the same method.

Characterization. The powder X-ray diffraction (XRD) patterns were collected on a Bruker D8 Focus diffractometer with $\mathrm{Cu} \mathrm{Ka}$ radiation $(\lambda=1.54056 \AA$, operated at $40 \mathrm{kV}$ and $40 \mathrm{~mA}$ ). The X-ray photoelectron spectroscopy (XPS) were obtained at $25^{\circ} \mathrm{C}$ on a PHI-Quantera SXM spectrometer with $\mathrm{Al} \mathrm{Ka}(1486.6 \mathrm{eV})$ radiation as the excitation source at ultra-high vacuum $\left(6.7 \times 10^{-8} \mathrm{~Pa}\right)$. All binding energies (BE) were determined with respect to the $\mathrm{C} 1 \mathrm{~s}$ line $(284.8 \mathrm{eV})$ originating from adventitious carbon. The morphologies of samples were investigated by the field emission scanning electron microscopy (FE-SEM) images obtained by a NOVA NanoSEM 450 instrument operated at the beam energy of $5 \mathrm{kV}$. High-angle annular dark-field (HAADF) scanning transmission electron microscopy (STEM) images and high resolution TEM images were obtained on a JEM-ARM200F TEM/ STEM with a guaranteed resolution of $0.08 \mathrm{~nm}$. Before microscopy examination, the catalyst powders were ultrasonically dispersed in ethanol and then a drop of the solution was put onto a copper grid coated with a thin lacey carbon film. Raman spectra were recorded on a Renishaw Raman spectrometer under ambient conditions, and the $514 \mathrm{~nm}$ line of a Spectra Physics $\mathrm{Ar}^{+}$laser was used for an excitation. The laser beam intensity was $2 \mathrm{~mW}$, and the spectrum slit width was $3.5 \mathrm{~cm}^{-1}$. Solid state ${ }^{27} \mathrm{Al}$ MAS NMR was performed at room temperature on a Bruker AVANCE III $500 \mathrm{MHz}$ solid-state NMR spectrometer, operating at a magnetic field of $11.7 \mathrm{~T}$. The corresponding ${ }^{27} \mathrm{Al}$ Larmor frequency was $130.28 \mathrm{MHz}$. All spectra were recorded at a sample spinning rate of $4 \mathrm{kHz}$. Each spectrum was acquired using a total of 2000 scans with a recycle delay time of $0.5 \mathrm{~s}$ and an acquisition time of $0.018 \mathrm{~s}$. All spectra were externally referenced (i.e., the $0 \mathrm{ppm}$ position) to an $1 \mathrm{M}$ $\mathrm{Al}\left(\mathrm{NO}_{3}\right)_{3}$ aqueous solution. The Pd dispersion was measured by $\mathrm{CO}$ chemisorption method on the Autochem $2920 \mathrm{II}$ apparatus. Before the test, the sample was pretreated in a flow $\left(40 \mathrm{~mL} \mathrm{~min}^{-1}\right)$ of $20 \mathrm{vol} \% \mathrm{O}_{2}$ balanced with Ar at $500{ }^{\circ} \mathrm{C}$ for 1 h. Then the sample was first reduced in a flow $\left(40 \mathrm{~mL} \mathrm{~min}^{-1}\right)$ of $5 \mathrm{vol} \% \mathrm{H}_{2}$ balanced with $\mathrm{N}_{2}$ at $200^{\circ} \mathrm{C}$ for $1 \mathrm{~h}$. After cooled to room temperature in a flow of $\mathrm{He}\left(40 \mathrm{~mL} \mathrm{~min}^{-1}\right)$, several pulses of $\mathrm{CO}(1 \mathrm{vol} \% \mathrm{CO}$ balanced with $\mathrm{He})$ were introduced into the sample until no more adsorption was observed. The stoichiometry for Pd: $\mathrm{CO}$ was taken be unity.

Computational method and models. Density functional theory (DFT) calculations were carried out using the Vienna Ab-initio Simulation Package (VASP). The spin-polarized projector augmented wave (PAW) method and the Perdew-BurkeErnzerhof (PBE) electron exchange-correlation functional of the generalized gradient approximation (GGA) were applied in our calculations. The kinetic energy cut-off for the wave function expanded in the plane-wave basis was set as $400 \mathrm{eV}$. To optimize the structures, the calculation was performed until the maximum force upon each relaxed atom was less than $0.05 \mathrm{eV}^{-1}$. The vacuum height was set as $10 \AA$ to eliminate the interaction between neighboring slabs. The adsorption energy $\left(E_{\text {ads }}\right)$ was calculated as followed Eq. (1):

$$
E_{\text {ads }}=-\left(E_{\text {substrate }}+E_{\text {PdO }}-E_{\text {total }}\right)
$$

where $E_{\text {total }}$ is the calculated total energy of the adsorption PdO cluster, $E_{\text {substrate }}$ is the energy of the clean substrate and $E_{\mathrm{PdO}}$ is the energy of optimized PdO cluster in the vacuum.

In order to study the adsorption of PdO cluster on $\gamma-\mathrm{Al}_{2} \mathrm{O}_{3}(110)$ surfaces, we used the following model: a $1 \times 2$ surface cell was used to construct a four-atomiclayer $\mathrm{Al}_{2} \mathrm{O}_{3}(110)$ slab, and the top three layers of the $\mathrm{Al}_{2} \mathrm{O}_{3}(110)$ slab were allowed to relax. The Brillouin-zone integration was performed along with a $2 \times 2 \times 1$ Monkhorst-Pack grid for the (110) surface slabs.

Catalytic combustion of methane and propane. The catalytic activity of the catalyst for $\mathrm{CH}_{4}$ combustion was evaluated in a fixed-bed reactor containing $200 \mathrm{mg}$ of catalyst at atmospheric pressure, and the feed gas consisted of $1 \mathrm{vol} \%$ $\mathrm{CH}_{4}, 20$ vol\% $\mathrm{O}_{2}, 10$ vol\% $\mathrm{H}_{2} \mathrm{O}$ (when used) and Ar. The total gas flow rate was $50 \mathrm{~mL} \mathrm{~min}^{-1}$, and the corresponding gas hourly space velocity (GHSV) was $15000 \mathrm{~mL} \mathrm{~h}^{-1} \mathrm{~g}_{\mathrm{cat}}{ }^{-1}$. The inlet and outlet $\mathrm{CH}_{4}$ concentration were measured by Agilent $\mathrm{GC} 7890 \mathrm{~A}$. The $\mathrm{CH}_{4}$ conversion $\left(\mathrm{X}_{\mathrm{CH} 4}\right)$ was calculated using the following Eq. (2):

$$
\mathrm{X}_{\mathrm{CH}_{4}} \%=\frac{\left[\mathrm{CH}_{4}\right]_{\text {in }}-\left[\mathrm{CH}_{4}\right]_{\text {out }}}{\left[\mathrm{CH}_{4}\right]_{\text {in }}} \times 100
$$

where $\left[\mathrm{CH}_{4}\right]_{\text {in }}$ and $\left[\mathrm{CH}_{4}\right]_{\text {out }}$ are the $\mathrm{CH}_{4}$ concentrations in the inlet and outlet gas, respectively.

The catalytic activity of the catalyst for $\mathrm{C}_{3} \mathrm{H}_{8}$ combustion was evaluated in a fixed-bed reactor containing $100 \mathrm{mg}$ of catalyst at atmospheric pressure, and the feed gas consisted of $0.2 \mathrm{vol} \% \mathrm{C}_{3} \mathrm{H}_{8}, 2 \mathrm{vol} \% \mathrm{O}_{2}$, and Ar. The total gas flow rate was $50 \mathrm{~mL} / \mathrm{min}$, and the corresponding GHSV was $30000 \mathrm{~mL} \mathrm{~h}^{-1} \mathrm{~g}_{\mathrm{cat}}{ }^{-1}$. The inlet and outlet $\mathrm{C}_{3} \mathrm{H}_{8}$ concentration were measured by by an online gas chromatograph (GC$2060)$ that was equipped with an FID. The $\mathrm{C}_{3} \mathrm{H}_{8}$ conversion $\left(\mathrm{X}_{\mathrm{C} 3 \mathrm{H} 8}\right)$ was calculated using the following Eq. (3):

$$
\mathrm{X}_{\mathrm{C}_{3} \mathrm{H}_{8}} \%=\frac{\left[\mathrm{C}_{3} \mathrm{H}_{8}\right]_{\text {in }}-\left[\mathrm{C}_{3} \mathrm{H}_{8}\right]_{\text {out }}}{\left[\mathrm{C}_{3} \mathrm{H}_{8}\right]_{\text {in }}} \times 100
$$

where $\left[\mathrm{C}_{3} \mathrm{H}_{8}\right]_{\text {in }}$ and $\left[\mathrm{C}_{3} \mathrm{H}_{8}\right]_{\text {out }}$ are the $\mathrm{C}_{3} \mathrm{H}_{8}$ concentrations in the inlet and outlet gas, respectively.

\section{Data availability}

All relevant data are available from the authors on reasonable request.

Received: 27 November 2018 Accepted: 9 March 2019

Published online: 08 April 2019

\section{References}

1. Jones, J. et al. Thermally stable single-atom platinum-on-ceria catalysts via atom trapping. Science 353, 150-154 (2016).

2. Cargnello, M. et al. Exceptional activity for methane combustion over modular Pd@ $\mathrm{CeO}_{2}$ subunits on functionalized $\mathrm{Al}_{2} \mathrm{O}_{3}$. Science 337, 713-717 (2012).

3. Peng, H. G. et al. Confined ultrathin Pd-Ce nanowires with outstanding moisture- and $\mathrm{SO}_{2}$-tolerance in methane combustion. Angew. Chem. Int. Ed. 57, 8953-8957 (2018).

4. Hashmi, A. S. K. \& Hutchings, G. J. Gold catalysis. Angew. Chem. Int. Ed. 45 , 7896-7936 (2006)

5. Deng, W. L. \& Flytzani-Stephanopoulos, M. On the issue of the deactivation of Au-ceria and Pt-ceria water-gas shift catalysts in practical fuel-cell applications. Angew. Chem. Int. Ed. 45, 2285-2289 (2006).

6. De Rogatis, L. et al. Embedded phases: a way to active and stable catalysts. ChemSusChem 3, 24-42 (2010).

7. Wang, A. Q., Li, J. \& Zhang, T. Heterogeneous single-atom catalysis. Nat. Rev Chem. 2, 65-81 (2018).

8. Zhang, Z. L. et al. Thermally stable single atom $\mathrm{Pt} / \mathrm{m}-\mathrm{Al}_{2} \mathrm{O}_{3}$ for selective hydrogenation and CO oxidation. Nat. Commun. 8, 16100 (2017).

9. Cui, T. L. et al. Encapsulating palladium nanoparticles inside mesoporous MFI zeolite nanocrystals for shape-selective catalysis. Angew. Chem. Int. Ed. 55, 9178-9182 (2016)

10. Liu, W. G. et al. A durable nickel single-atom catalyst for hydrogenation reactions and cellulose valorization under harsh conditions. Angew. Chem. Int. Ed. 57, 7071-7075 (2018) 
11. He, J. J., Wang, C. X., Zheng, T. T. \& Zhao, Y. K. Thermally induced deactivation and the corresponding strategies for improving durability in automotive threeway catalysts. Johnson Matthey. Technol. Rev. 60, 196-203 (2016).

12. Lang, R. et al. Non defect-stabilized thermally stable single-atom catalyst. Nat. Commun. 10, 234-243 (2019).

13. Hansen, T. W., Delariva, A. T., Challa, S. R. \& Datye, A. K. Sintering of catalytic nanoparticles: particle migration or Ostwald ripening? Accounts Chem. Res. 46, 1720-1730 (2013).

14. Zhang, $\mathrm{Z}$. L. et al. Thermally stable single atom $\mathrm{Pt} / \mathrm{m}-\mathrm{Al}_{2} \mathrm{O}_{3}$ for selective hydrogenation and CO oxidation. Nat. Commun. 8, 16100 (2017).

15. Ouyang, R., Liu, J. X. \& Li, W. X. Atomistic theory of Ostwald ripening and disintegration of supported metal particles under reaction conditions. J. Am. Chem. Soc. 135, 1760-1771 (2013).

16. Zhan, W. C. et al. Surfactant-assisted stabilization of Au colloids on solids for heterogeneous catalysis. Angew. Chem. Int. Ed. 56, 4494-4498 (2017).

17. Zhan, W. C. et al. A sacrificial coating strategy toward enhancement of metalsupport interaction for ultrastable Au nanocatalysts. J. Am. Chem. Soc. 138, 16130-16139 (2016).

18. Tang, H. L. et al. Ultrastable hydroxyapatite/titanium-dioxide-supported gold nanocatalyst with strong metal-support interaction for carbon monoxide oxidation. Angew. Chem. Int. Ed. 55, 10606-10611 (2016).

19. Wang, L., Xu, S. D., He, S. X. \& Xiao, F. S. Rational construction of metal nanoparticles fixed in zeolite crystals as highly efficient heterogeneous catalysts. Nano Today 20, 74-83 (2018).

20. Farmer, J. A. \& Campbell, C. T. Ceria maintains smaller metal catalyst particles by strong metal-support bonding. Science 329, 933-936 (2010).

21. Liu, X. Y., Wang, A. Q., Zhang, T. \& Mou, C. Y. Catalysis by gold: new insights into the support effect. Nano Today 8, 403-416 (2013).

22. Li, W. Z. et al. A general mechanism for stabilizing the small sizes of precious metal nanoparticles on oxide supports. Chem. Mater. 26, 5475-5481 (2014).

23. Tang, H. L. et al. Strong metal-support interactions between gold nanoparticles and nonoxides. J. Am. Chem. Soc. 138, 56-59 (2016).

24. Liu, X. Y. et al. Strong metal-support interactions between gold nanoparticles and $\mathrm{ZnO}$ nanorods in $\mathrm{CO}$ oxidation. J. Am. Chem. Soc. 134, 10251-10258 (2012).

25. Zhang, J. et al. Sinter-resistant metal nanoparticle catalysts achieved by immobilization within zeolite crystals via seed-directed growth. Nat. Catal. 1, 540-546 (2018).

26. Liu, J., Ji, Q. M., Imai, T., Ariga, K. \& Abe, H. Sintering-resistant nanoparticles in wide-mouthed compartments for sustained catalytic performance. Sci. Rep. 7, 41773-41780 (2017)

27. Peterson, E. J. et al. Low-temperature carbon monoxide oxidation catalysed by regenerable atomically dispersed palladium on alumina. Nat. Commun. $\mathbf{5}$, 4885 (2014).

28. Wang, G. X. et al. Fish-in-hole: rationally positioning palladium into traps of zeolite crystals for sinter-resistant catalysts. Chem. Commun. 54, 3274-3277 (2018).

29. Li, W. Z. et al. Stable platinum nanoparticles on specific $\mathrm{MgAl}_{2} \mathrm{O}_{4}$ spinel facets at high temperatures in oxidizing atmospheres. Nat. Commun. 4, 3481-3488 (2013).

30. Yang, X. W. et al. Surface tuning of noble metal doped perovskite oxide by synergistic effect of thermal treatment and acid etching: a new path to highperformance catalysts for methane combustion. Appl. Catal. B 239, 373-382 (2018).

31. Trueba, M. \& Trasatti. S. P. $\gamma$-Alumina as a support for catalysts: a review of fundamental aspects. Eur. J. Inorg. Chem. 2005, 3393-3403 (2005).

32. Rascon, F., Wischert, R. \& Coperet., C. Molecular nature of support effects in single-site heterogeneous catalysts: silica vs. alumina. Chem. Sci. 2, 1449-1456 (2011).

33. Kang, J. H., Menard, L. D., Nuzzo, R. G. \& Frenkel, A. I. Unusual non-bulk properties in nanoscale materials: thermal metal-metal bond contraction of $\gamma$ alumina-supported Pt catalysts. J. Am. Chem. Soc. 128, 12068-12069 (2006).

34. Kwak, J. H. et al. Coordinatively unsaturated $\mathrm{Al}^{3+}$ centers as binding sites for active catalyst phases of platinum on $\gamma-\mathrm{Al}_{2} \mathrm{O}_{3}$. Science 325, 1670-1673 (2009).

35. Mei, D. H. et al. Unique role of anchoring penta-coordinated $\mathrm{Al}^{3+}$ sites in the sintering of $\gamma-\mathrm{Al}_{2} \mathrm{O}_{3}$-supported Pt catalysts. J. Phys. Chem. Lett. 1, 2688-2691 (2010).

36. Tang, N. F. et al. Coordinatively unsaturated $\mathrm{Al}^{3+}$ sites anchored subnanometric ruthenium catalyst for hydrogenation of aromatics. ACS Catal. 7, 5987-5991 (2017)

37. Shi, L. et al. $\mathrm{Al}_{2} \mathrm{O}_{3}$ nanosheets rich in pentacoordinate $\mathrm{Al}^{3+}$ ions stabilize PtSn clusters for propane dehydrogenation. Angew. Chem. Int. Ed. 54, 13994-13998 (2015).

38. Kovarik, L. et al. Tomography and high-resolution electron microscopy study of surfaces and porosity in a plate-like $\gamma-\mathrm{Al}_{2} \mathrm{O}_{3}$. J. Phys. Chem. C 117, 179-186 (2013).
39. Wang, J. et al. Thin porous alumina sheets as supports for stabilizing gold nanoparticles. ACS Nano 7, 4902-4910 (2013).

40. Kwak, J. H. et al. Role of pentacoordinated $\mathrm{Al}^{3+}$ ions in the high temperature phase transformation of $\gamma-\mathrm{Al}_{2} \mathrm{O}_{3}$. J. Phys. Chem. C 112, 9486-9492 (2008)

41. Jiang, H., Lee, P. S. \& Li, C. Z. 3D carbon based nanostructures for advanced supercapacitors. Energy Environ. Sci. 6, 41-53 (2013).

42. Georgakilas, V. et al. Noncovalent functionalization of graphene and graphene oxide for energy materials, biosensing, catalytic, and biomedical applications. Chem. Rev. 116, 5464-5519 (2016).

43. Schneider, J. et al. Understanding $\mathrm{TiO}_{2}$ photocatalysis: mechanisms and materials. Chem. Rev. 114, 9919-9986 (2014).

44. Zhou, J. K. et al. Synthesis of self-organized polycrystalline F-doped $\mathrm{TiO}_{2}$ hollow microspheres and their photocatalytic activity under visible light. J. Phys. Chem. C 112, 5316-5321 (2008).

45. Zhang, J. S., Chen, Y. \& Wang, X. C. Two-dimensional covalent carbon nitride nanosheets: synthesis, functionalization, and applications. Energ. Environ. Sci. 8, 3092-3108 (2015).

46. Zhang, J. S., Zhang, M. W., Yang, C. \& Wang, X. C. Nanospherical carbon nitride frameworks with sharp edges accelerating charge collection and separation at a soft photocatalytic interface. Adv. Mater. 26, 4121-4126 (2014).

47. Ma, T. Y., Dai, S., Jaroniec, M. \& Qiao, S. Z. Graphitic carbon nitride nanosheet-carbon nanotube three-dimensional porous composites as highperformance oxygen evolution electrocatalysts. Angew. Chem. Int. Ed. 53, $7281-7285$ (2014)

48. Lu, A. H., Hao, G. P. \& Sun, Q. Design of three-dimensional porous carbon materials: From static to dynamic skeletons. Angew. Chem. Int. Ed. 52, 7930-7932 (2013)

49. Yan, Z. et al. Mechanical assembly of complex, 3D mesostructures from releasable multilayers of advanced materials. Sci. Adv. 2, e1601014 (2016).

50. Zhu, C. et al. Supercapacitors based on three-dimensional hierarchical graphene aerogels with periodic macropores. Nano. Lett. 16, 3448-3456 (2016).

51. Zhang, Q. et al. Three-dimensional interconnected $\mathrm{Ni}(\mathrm{Fe}) \mathrm{O}_{\mathrm{x}} \mathrm{H}_{\mathrm{y}}$ nanosheets on stainless steel mesh as a robust integrated oxygen evolution electrode. Nano Res. 11, 1294-1300 (2018).

52. Kim, J. E., Oh, J. H., Kotal, M., Koratkar, N. \& Oh, I. K. Self-assembly and morphological control of three-dimensional macroporous architectures built of two-dimensional materials. Nano Today 14, 100-123 (2017).

53. $\mathrm{Yu}, \mathrm{Z}$. Y. et al. Segregation-induced ordered superstructures at general grain boundaries in a nickel-bismuth alloy. Science 358, 97-101 (2017).

54. Yu, Z. Y., Luo, J., Harmer, M. P. \& Zhu, J. An order-disorder transition in surface complexions and its influence on crystal growth of boron-rich nanostructures. Crystal Growth and Design 15, 3547-3551 (2015).

55. Sun, M. H. et al. Applications of hierarchically structured porous materials from energy storage and conversion, catalysis, photocatalysis, adsorption, separation, and sensing to biomedicine. Chem. Soc. Rev. 45, 3479-3563 (2016).

56. Chen, L. H. et al. Highly stable and reusable multimodal zeolite TS-1 based catalysts with hierarchically interconnected three-level micro-mesomacroporous structure. Angew. Chem. Int. Ed. 50, 11156-11161 (2011).

57. Nishihata, Y. et al. Self-regeneration of a Pd-perovskite catalyst for automotive emissions control. Nature 418, 164-167 (2002).

58. Kang, H. K., Jun, Y. W., Park, J. I., Lee, K. B. \& Cheon, J. Synthesis of porous palladium superlattice nanoballs and nanowires. Chem. Mater. 12, 3530-3532 (2000).

59. McBride, J. R., Hass, K. C. \& Weber, W. H. Resonance-Raman and latticedynamics studies of single-crystal PdO. Phys. Rev., B 44, 5016-5028 (1999).

60. Zhang, $\mathrm{H}$. et al. In situ dynamic tracking of heterogeneous nanocatalytic processes by shell-isolated nanoparticle-enhanced Raman spectroscopy. Nat. Commun. 8, 15447-15455 (2017)

61. Bell, W. E., Inyard, R. E. \& Tagami, M. Dissociation of palladium oxide. J. Phys. Chem. C 70, 3735-3736 (1966).

62. Farrauto, R. J., Hobson, M. C., Kennelly, T. \& Waterman, E. M. Catalytic chemistry of supported palladium for combustion of methane. Appl. Catal. A 81, 227-237 (1992).

63. Coster, D., Blumenfeld, A. L. \& Fripiat, J. J. Lewis acid sites and surface aluminum in aluminas and zeolites: a high-resolution NMR study. J. Phys. Chem. 98, 6201-6211 (1994).

64. $\mathrm{Li}, \mathrm{X}$. J. et al. The role of alumina in the supported $\mathrm{Mo} / \mathrm{HBeta}-\mathrm{Al}_{2} \mathrm{O}_{3}$ catalyst for olefin metathesis: a high-resolution solid-state NMR and electron microscopy study. J. Catal. 250, 55-56 (2007).

65. Pecharromán, C., Sobrados, I., Iglesias, J. E., Gonzalez-Carreno, T. \& Sanz, J. Thermal evolution of transitional aluminas followed by NMR and IR spectroscopies. J. Phys. Chem. B 103, 6160-6170 (1999).

66. Murata, K. et al. The metal-support interaction concerning the particle size effect of $\mathrm{Pd} / \mathrm{Al}_{2} \mathrm{O}_{3}$ on methane combustion. Angew. Chem. Int. Ed. 56, 15993-15997 (2017). 
67. Colussi, S. et al. Nanofaceted Pd-O sites in Pd-Ce surface superstructures: enhanced activity in catalytic combustion of methane. Angew. Chem. Int. Ed. 48, 8481-8484 (2009).

68. Nilsson, J. et al. Chemistry of supported palladium nanoparticles during methane oxidation. ACS Catal. 5, 2481-2489 (2015).

69. Zhu, Z. Z. et al. Influences of Pd precursors and preparation method on the catalytic performances of Pd-only close-coupled catalysts. J. Ind. Eng. Chem. 18, 2135-2140 (2012).

70. Toso, A., Colussi, S., Padigapaty, S., de Leitenburg, C. \& Trovarelli, A. High stability and activity of solution combustion synthesized Pd-based catalysts for methane combustion in presence of water. Appl. Catal. B 230, 237-245 (2018).

\section{Acknowledgements}

W.C.Z. and Y.L.G. appreciate the financial support from the National Key Research and Development Program of China (2016YFC0204300), the National Natural Science Foundation of China (21577034), the 111 project (B08021) and Shanghai Pujiang Program (17PJD012). Y.G. appreciates the National Natural Science Foundation of China (21577035). Z.Y.Y. appreciates the National Natural Science Foundation of China (51871058 and 51701170). S.D. were supported by the US Department of Energy, Office of Science, Basic Energy Sciences, Chemical Sciences, Geosciences, and Biosciences Division.

\section{Author contributions}

W.C.Z., J.S.Z. and S.D. conceived and designed the experiments. X.W.Y. and Q.L. performed all the experiments and analysed all the data. E.J.L. worked for the AFM images. Z.Q.W. and X.Q.G. completed the DFT calculation part. Z. Y. Y. worked for TEM images. Y.G. and L.W. assisted to synthesize catalysts. Y.L.G. assisted to analyse characterization results. All authors discussed the results and commented on the manuscript. W.C.Z. and J.S.Z. wrote the paper, and S.D. revised the paper.

\section{Additional information}

Supplementary Information accompanies this paper at https://doi.org/10.1038/s41467019-09662-4.

Competing interests: The authors declare no competing interests.

Reprints and permission information is available online at http://npg.nature.com/ reprintsandpermissions/

Journal Peer Review Information: Nature Communications thanks Abhaya Datye, and other anonymous reviewer(s) for their contribution to the peer review of this work. Peer reviewer reports are available.

Publisher's note: Springer Nature remains neutral with regard to jurisdictional claims in published maps and institutional affiliations.

(c) (i) Open Access This article is licensed under a Creative Commons Attribution 4.0 International License, which permits use, sharing, adaptation, distribution and reproduction in any medium or format, as long as you give appropriate credit to the original author(s) and the source, provide a link to the Creative Commons license, and indicate if changes were made. The images or other third party material in this article are included in the article's Creative Commons license, unless indicated otherwise in a credit line to the material. If material is not included in the article's Creative Commons license and your intended use is not permitted by statutory regulation or exceeds the permitted use, you will need to obtain permission directly from the copyright holder. To view a copy of this license, visit http://creativecommons.org/ licenses/by/4.0/.

(C) The Author(s) 2019 